\title{
Komunikasi Lintas Budaya Masyarakat Dayak Dalam Menjaga Kerukunan Hidup Umat Beragama
}

\author{
H.H. Daniel Tamburian \\ Fakultas Ilmu Komunikasi Universitas Tarumanagara \\ tamburian@gmail.com
}

\begin{abstract}
This research entitled Cross Cultural Communication Dayak Indigenous in Maintaining Harmony Interfaith Religious Life in Sanggau District West Kalimantan. The lives of people from different backgrounds are vulnerable to horizontal conflicts. The presence of immigrants from various tribes and religions in the Sanggau district figure has the potential to create a new conflict if it is not managed by a cultural approach by the local community. This research uses a qualitative approach and uses constructivist paradigm, where the source data obtained from in-depth interviews prioritizing the depth (quality) of the informants The purpose of this study is to describe intercultural communication of indigenous Dayak community with the immigrant community in Sanggau District Sanggau in maintaining the harmony of religious life. Dialogic communication is a factor that forms a harmonious relationship in a relation. The results of this study indicate that the Dayak community is very open to migrants and in solving their problems put forward a dialogical communication with their Dayak customary approach which is represented by the local Dayak Customary Council.
\end{abstract}

Keyword: Dayak, intercultural communication, religious tolerance, Sanggau,

\begin{abstract}
Abstrak
Penelitian ini berjudul Komunikasi Lintas Budaya Masyarakat Adat Dayak dalam Memelihara Kerukunan Hidup Antarumat Beragama di Kota Sosok Kabupaten Sanggau Kalimantan Barat. Kehidupan masyarakat yang berasal dari latar belakang yang berbeda rentan terhadap konflik horizontal. Kehadiran para pendatang dari berbagai suku dan agama di kota Sosok Kabupaten Sanggau berpotensi melahirkan konflik baru bila tidak dikelola dengan pendekatan budaya oleh masyarakat setempat. Penelitian ini menggunakan pendekatan kualitatif dan menggunakan paradigma konstruktivis, dimana sumber data diperoleh dari wawancara mendalam dengan mengutamakan kedalaman (kualitas) dari para informan Tujuan dari penelitian ini adalah mendeskripsikan komunikasi antarbudaya masyarakat adat Dayak dengan masyarakat pendatang di Kota Sosok Kabupaten Sanggau dalam menjaga kerukunan hidup beragama. Komunikasi dialogis merupakan faktor yang membentuk hubungan yang harmonis dalam sebuah relasi. Hasil penelitian ini menunjukkan bahwa masyarakat ada Dayak sangat terbuka dengan pendatang dan dalam menyelesaikan masalah mereka mengedepankan sebuah komunikasi yang dialogis dengan pendekatan adat Dayak mereka yang diwakili oleh Dewan Adat Dayak setempat.
\end{abstract}

Kata Kunci : Dayak, komunikasi antarbudaya, Sanggau, toleransi agama 


\section{Pendahuluan}

Indonesia merupakan Negara kepulauan yang terdiri dari berbagai latar belakang suku, agama, ras, dan antargolongan (SARA). Ribuan pulau terbentang sepanjang khatulistiwa di wilayah Asia Tenggara yang masuk wilayah Indonesia. Kondisi geografis Indonesia yang begitu luas dan strategis membuat banyak negara di dunia memperebutkannya. Banyaknya kepentingan negara asing yang mencoba menguasai Indonesia membuat negeri khatulistiwa ini rentan terhadap konflik horizontal. Pertarungan kekuatan negara-negara adidaya yang ingin menanamkan pengaruhnya di Indonesia nampak jelas terlihat di bidang ekonomi dan politik. Kekayaan bumi pertiwi yang luar biasa besar merupakan magnet yang kuat untuk menarik negara adidaya dan negara tetangga untuk berebut pengaruh di Indonesia demi mendapatkan potongan kekayaan bumi pertiwi.

Selain kekayaan alam, Indonesia memiliki kekayaan budaya dan seni dari berbagai suku yang mendiami pulau-pulau di Indonesia. Keragaman budaya yang seharusnya bisa mempererat persatuan Indonesia dapat dijadikan sebuah pemantik konflik horizontal. Saat ini bahaya konflik horizontal nyata di depan mata dengan diangkatnya isu-isu sensitif yang berbau SARA dalam pemilihan kepala daerah (PILKADA) seperti yang terjadi di Jakarta dengan kasus Basuki Tjahaja Purnama (AHOK).

Isu SARA merupakan faktor utama penyebab konflik horizontal yang terjadi di Indonesia. Konflik horizontal berlatar belakang SARA beberapa kali terjadi di Kalimantan. Konflik antara suku Dayak dengan Madura beberapa kali terjadi hingga mencapai puncaknya pada tahun 1996 dan 2001. Selain konflik antara Dayak dengan Madura, ada juga konflik antara suku Melayu dengan suku Madura yang terjadi pada tahun 1999 yang kemudian menyeret suku Dayak untuk terlibat di dalamnya. Tragedi kerusuhan di Kalimantan antara suku Dayak dengan suku Madura memiliki sejarah yang cukup panjang. Sejak tahun 1960an sudah terjadi konflik Dayak-Madura sebanyak 11 kali. Secara geografis orang Madura berada di wilayah Jawa dan menjadi bagian dari provinsi Jawa Timur, dan secara budaya orang Madura memiliki kedekatan dengan orang Jawa.

Budaya memengaruhi orang yang berkomunikasi begitu kata Samovar dan Porter (Mulyana \& Rakhmat, 2006). Selanjutnya Samovar \& Porter mengatakan bahwa budaya bertanggung jawab atas seluruh perbendaharaan perilaku komunikatif dan makna yang dimiliki setiap orang. Sebagai akibatnya, perbendaharaan-perbendaharaan yang dimiliki oleh dua orang yang berbeda budaya akan berbeda pula dan tentunya dapat menimbulkan banyak kesulitan.

Sementara dalam berkomunikasi setiap komunikator dituntut untuk mampu memahami komunikannya. Dalam berkomunikasi lintas budaya seorang komunikator wajib mengenal komunikan dengan memahami frame of reference komunikan. Kamus Webster mendefinisikan frame of reference sebagai a set of ideas, conditions, or assumptions that determine how something will be approached, perceived, or understood. Frame of reference merupakan konsep yang dikembangkan oleh Wilbur Schramm, yang mengembangkan model komunikasi yang sangat terkenal dimana salah satu komponen dari konsep 
H.H. Daniel Tambuarian : Komunikasi Lintas Budaya Masyarakat Dayak Dalam Menjaga Kerukunan Hidup Umat Beragama

tersebut adalah field of experience, yang sering juga disebut dengan istilah frame of reference di atas.

Field of experience dalam konsep Schramm adalah segala sesuatu yang memengaruhi pemahaman dan interpretasi seseorang terhadap sebuah pesan seperti budaya, latar belakang sosial, keyakinan, pengalaman, nilai-nilai, dan aturan-aturan. Pesan yang sama dapat ditafsirkan secara berbeda oleh orang yang berbeda. Jika kata-kata dan simbol-simbol yang digunakan oleh para partisipan (komunikator dan komunikan) biasa digunakan kedua belah pihak, maka akan terjadi komunikasi secara efisien. Sebagai contoh, pengalaman penulis ketika bekerja dalam sebuah lingkungan multiculture. Suatu ketika direktur sekolah, seorang berkebangsaan Australia, menulis memo kepada kepala sekolah dengan menggunakan tinta warna merah. Kepala sekolah kaget karena menyangka direktur sekolah marah kepadanya. Kepala sekolah kemudian bertanya kepada direktur sekolah tentang kesalahannya. Direktur sekolah kaget karena merasa tidak pernah marah kepada kepala sekolah. Kepala sekolah mengatakan bahwa tinta merah yang digunakan menunjukkan bahwa direktur sekolah marah. Direktur sekolah kemudian menjelaskan bahwa saat menulis memo tersebut di meja dia hanya ada ballpoint berwarna merah.

Beberapa contoh perbedaan budaya dan bahasa pada beberapa suku di Indonesia yang bisa berakibat pada kesalahpahaman di antara komunikan. Kata "atos" dalam bahasa Sunda memiliki arti sudah, sementara bahasa Jawa berarti keras. Bahasa Sunda "cokot" berarti ambil, sedangkan bahasa Jawa berarti gigit. Jika orang Sunda berkata kepada orang Jawa "tolong cokot batunya" maka bisa jadi orang Jawa marah karena mengira dirinya disuruh gigit batu.

Bukan hanya bahasa, dalam hal budaya banyak perbedaan diantara sukusuku di Indonesia yang bisa mengakibatkan konflik horizontal. Orang Minahasa atau yang biasa dikenal orang Manado sangat suka dan merasa tersanjung bila makanan yang dihidangkan dihabiskan oleh tamu, apalagi jika tamu tersebut minta tambah. Tapi tidak demikian halnya dengan beberapa suku bangsa yang punya tradisi menyisakan sedikit makanan atau air minum yang dihidangkan, karena bila dihabiskan maka dianggap tidak sopan.

Benturan budaya tidak dapat dihindari manakala seorang individu atau sekelompok orang berinteraksi dengan kelompok lain yang berbeda bahasa dan budaya. Benturan budaya di antara kelompok yang berbeda dapat berakibat kedua belah pihak berusaha saling memahami, dapat juga berujung pada konflik. Konflik antara suku Dayak-Madura dan Melayu-Madura di Kalimantan merupakan contoh kasus bagaimana benturan budaya berakhir dengan konflik di bumi Borneo.

Jika melihat sejarah kedatangan orang Madura ke Kalimantan yang sudah berlangsung sejak era kolonial Belanda, maka cukup mengherankan jika timbul konflik seperti yang terjadi di atas. Jika proses adaptasi berlangsung dengan baik selama bertahun-tahun tentunya konflik di atas tidak terjadi. Namun sayangnya, konflik tersebut tidak hanya terjadi sekali, tapi berkali-kali. Sementara orangorang Jawa dan suku-suku lain yang juga merantau ke Kalimantan justru tidak pernah mengalami konflik dengan orang asli Kalimantan maupun orang Melayu. 
Namun, ada yang menarik dalam fenomena komunikasi antar budaya antara suku Jawa yang merantau ke Kalimantan. Orang Jawa mampu beradaptasi dan membangun komunikasi dengan penduduk asli setempat. Bukan hanya orang Jawa saja, tapi ada juga suku Minang, dan Batak yang berdiam di kota Sosok dan dapat hidup rukun dengan masyarakat Dayak setempat. Penelitian ini bertujuan mendeskripsikan bagaimana kerukunan hidup beragama di Kecamatan Sosok dapat terjaga hingga saat ini dilihat dari kacamata komunikasi antar budaya masyarakat adat Dayak.

Berdasarkan latar belakang masalah di atas, maka rumusan masalah penelitian ini adalah: bagaimana komunikasi lintas budaya masyarakat adat dayak dalam memelihara kerukunan hidup antarumat beragama di Kota Sosok Kabupaten Sanggau Kalimantan Barat.

Salah satu penelitian terdahulu dilakukan Sari (2015) yang mengkaji konflik budaya dalam konstruksi kecantikan pada diri perempuan asia. Penelitian tersebut dilakukan dengan metode semiotic dengan membedah iklan produk kecantikan ternama di Indonesia, yaitu Pond's. Hasil penelitian menunjukkan terjadi pembentukan kesadaran palsu oleh pihak pengusaha pemilik produk (kapitalis) untuk membentuk konstruksi kecantikan yang menguntungkan bagi pihak kapitalis. Kemudian, penelitian yang dilakukan oleh penulis memiliki perbedaan dalam hal peneliti terjun langsung ke dalam kelompok masyarakat yang diteliti untuk melihat lebih jauh komunikasi antar budaya yang terjadi dalam membentuk kerukunan.

Berikut akan dijelaskan beberapa konsep teori yang digunakan dalam penelitian ini. Pertama adalah teori identitas budaya. Identitas merupakan sebuah konsep yang abstrak, itulah sebabnya identitas tidak mudah untuk diartikan. Gardiner dan Kosmitzki memandang identitas sebagai definisi diri seseorang sebagai individu yang berbeda dan terpisah, termasuk perilaku, kepercayaan, dan sikap. Sementara Ting-Toomey mendefinisikan identitas sebagai konsep diri yang direfleksikan atau gambaran diri bahwa kita berasal dari keluarga, gender, budaya, etnis, dan proses sosialisasi individu.

Sementara identitas budaya menurut pendapat Fong, sebagaimana dikutip oleh Samovar adalah:

"identifikasi komunikasi dari sistem perilaku simbolis verbal dan non-verbal yang memiliki arti dan yang dibagikan diantara anggota kelompok yang memiliki rasa saling memiliki dan yang membagi tradisi, warisan, bahasa, dan norma-norma yang sama. Identitas budaya merupakan konstruksi sosial". (Samovar, Porter, dan McDaniel, 2010)

Samovar mengatakan bahwa identitas merupakan hal yang dinamis dan beragam. Artinya, identitas itu bukan merupakan sesuatu hal yang statis, namun berubah menurut pengalaman seseorang. Menurutnya lagi setiap orang memiliki lebih dari satu identitas.

Beberapa peneliti membuat kategori untuk mengelompokkan berbagai jenis identitas. Menurut Turner ada tiga kategori untuk mengklasifikasikan identitas, yaitu: identitas manusia, identitas sosial, dan identitas pribadi. 
H.H. Daniel Tambuarian : Komunikasi Lintas Budaya Masyarakat Dayak Dalam Menjaga Kerukunan Hidup Umat Beragama

Dikatakan bahwa identitas manusia merupakan pandangan yang menghubungkan seseorang dengan seluruh manusia dan memisahkan seseorang dari bentuk kehidupan yang lain. Sedangkan identitas sosial adalah perwakilan dari kelompok di mana seseorang tergabung, seperti ras, etnisitas, pekerjaan, umur, kampung halaman, dan lain-lain. Terakhir, identitas pribadi timbul dari hal-hal yang membedakan seseorang dari yang lainnya dan menandakan seseorang sebagai pribadi yang special dan unik.

Adapun Hall menawarkan tiga level identitas yang tergantung dari konteksnya yang mungkin menonjol atau tidak menonjol dalam hubungan seseorang dengan yang lain. Ketiga level identitas tersebut adalah identitas pribadi, identitas hubungan, dan identitas komunal. Identitas pribadi adalah halhal yang membuat seseorang unik dan berbeda dari orang lain. Identitas hubungan adalah hasil dari hubungan seseorang dengan orang lain. Identitas komunal biasanya dihubungkan dengan komunitas berskala besar seperti kewarganegaraan, etnis, gender, agama, dan aliran politik (Samovar, Porter dan McDaniel, 2010).

Pembahasan tentang identitas budaya seringkali dikaitkan dengan konsep stereotipe. Stereotipe menurut Samovar adalah bentuk kompleks dari pengelompokkan yang secara mental mengatur pengalaman seseorang dan mengarahkan sikap seseorang dalam menghadapi orang-orang tertentu. Stereotipe bisa positif, bisa juga negatif. Stereotipe tidak dibawa sejak lahir, tapi dipelajari. Stereotipe dapat mengembangkan rasa takut terhadap orang di luar kelompoknya. Dalam beberapa kesempatan, stereotipe merupakan hasil dari persepsi yang terbatas, malas, dan sesat. Masalah dalam stereotipe adalah overgeneralisasi dan penilaian negatif (tindakan atau prasangka) terhadap anggota kelompok. Stereotipe bukan sekedar masalah pengotak-kotakkan atau pengelompokkan.

Model komunikasi Wilbur Schramm sekalipun masuk kategori teori komunikasi klasik, tapi masih relevan untuk digunakan sebagai pisau analisa komunikasi antar budaya. Schramm memandang bahwa komunikasi adalah sebuah proses yang tanpa akhir, bukan proses yang diawali sesuatu dan diakhiri sesuatu. Komunikasi merupakan sebuah proses yang bersifat circular bukan linear dan manusia adalah "little switchboard centres handling and rerouting the great endless current of information".

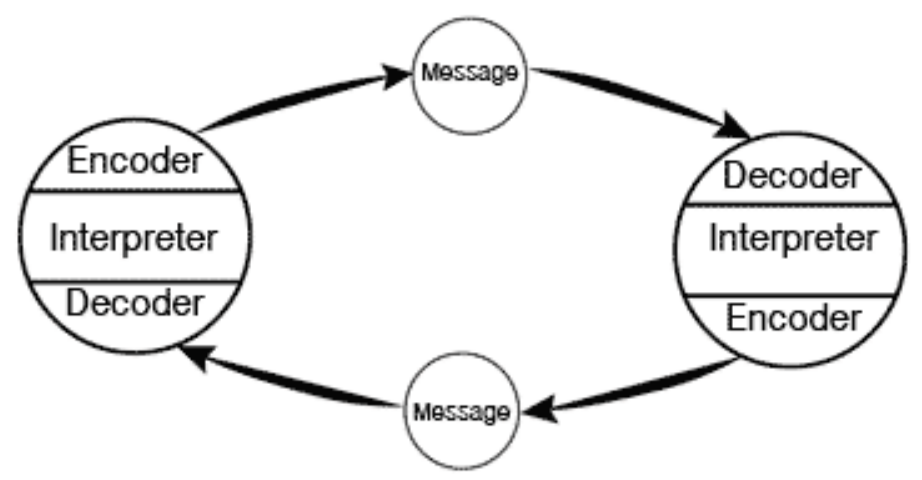

Gambar 1: Model Komunikasi Wilbur Schramm 


\section{Metode Penelitian}

Penelitian ini menggunakan paradigm konstruktivis. Menurut paradigma konstruktivisme, realitas sosial yang diamati oleh seseorang tidak dapat digeneralisasikan pada semua orang yang biasa dilakukan oleh kaum positivis. Paradigma konstruktivisme menilai perilaku manusia secara fundamental berbeda dengan perilaku alam karena manusia bertindak sebagai agen yang mengkonstruksi dalam realitas sosialnya, baik melalui pemberian makna maupun pemahaman perilaku di kalangan manusia sendiri. Kajian paradigma konstruktivisme ini menempatkan posisi peneliti setara dan sebisa mungkin masuk dengan subjeknya, dan berusaha memahami serta mengkonstruksikan sesuatu yang menjadi pemahaman si subjek yang akan diteliti.

Pendekatan subjektif muncul karena menganggap manusia berbeda dengan suatu benda. Manusia dianggap bebas dan aktif dalam berperilaku dan memaknai realitas sosial. Realitas merupakan hasil interaksi antarindividu.

Penelitian ini dilakukan dengan menggunakan pendekatan kualitatif. Menurut Creswell (2003), mengungkapkan bahwa penelitian kualitatif merupakan proses untuk memahami masalah melalui penggambaran holistik atas masalah tersebut yang dibentuk dengan kata-kata, melaporkan dengan terperinci sesuai sudut pandang informan, dan disusun dalam latar ilmiah. Istilah deskriptif ditujukan untuk mendeskripsikan fenomena-fenomena yang ada (dapat berupa bentuk, aktivitas, karakteristik, perubahan, hubungan, kesamaan, dan perbedaan antara fenomena yang satu dengan fenomena lainnya). Data diperoleh melalui wawancara dan juga obervasi partisipan. Narasumber utama dalam penelitian ini adalah Bapak Dionus Haryono yang merpakan Ketua Dewan Adat Dayak kota Sosok.

\section{Hasil Penemuan dan Diskusi}

Masyarakat Dayak dikenal dengan sikap yang menjunjung tinggi adatnya dalam kehidupan dengan sesama suku Dayak dan dalam pergaulan dengan sukusuku lain yang merantau di daerahnya. Bila ada permasalahan yang muncul di tengah-tengah masyarakat biasanya diselesaikan dengan cara adat masing-masing sebelum dibawa ke ranah hukum. Bila ada pelanggaran yang bersifat pidana, maka selain ada proses hukum terhadap pelanggaran pidana ada juga penerapan hukum adat setempat. Dengan kata lain, hukum adat berlaku kepada semua orang yang menetap di kota Sosok tidak terkecuali para pendatang. Dewan adat setempat menjadi lembaga yang memantau pelaksanaan dan penegakkan hukum adat Dayak.

Hukum adat merupakan produk budaya dari sebuah suku bangsa. Dengan mengedepankan proses hukum adat dalam menyelesaikan setiap perkara atau masalah yang muncul di masyarakat menunjukkan bahwa suku Dayak lebih cenderung untuk melakukan pendekatan budaya bila terjadi konflik atau masalah. Suku Dayak menunjukkan identitas mereka melalui penerapan hukum adatnya. 
H.H. Daniel Tambuarian : Komunikasi Lintas Budaya Masyarakat Dayak Dalam Menjaga Kerukunan Hidup Umat Beragama

Identitas budaya masyarakat Dayak yang mendominasi keseharian mampu mengatasi perbedaan latar belakang agama di antara sesama. Bagi masyarakat Dayak agama bukan penghalang untuk saling berinteraksi dengan suku-suku lain yang ada di kota Sosok. Perbedaan agama dengan suku-suku lain juga tidak akan pernah menjadi potensi atau akar dari sebuah konflik selama semua orang, baik itu orang Dayak mapun warga pendatang, tunduk pada hukum adat yang berlaku.

Selama ini konflik yang berlatar belakang perbedaan agama belum pernah terjadi dikarenakan orang Dayak sangat terbuka dengan berbagai aliran agama yang ada. Di dalam sebuah keluarga suku Dayak dapat ditemukan anggota keluarganya yang menganut aliran agama yang berbeda-beda, namun sesama anggota keluarga tetap hidup harmonis. Kehidupan yang harmonis di tengahtengah anggota keluarga yang berbeda agama juga direfleksikan dalam pergaulan dan interaksi antara suku Dayak dengan suku-suku lain yang menetap di kota Sosok.

Bagi masyarakat Dayak bila ada orang yang datang dari suku lain dan berbeda agama dengan para pendatang datang dengan cara baik-baik ke wilayahnya, maka masyarakat Dayak menerima dengan baik pula. Di samping itu masyarakat Dayak memandang para pendatang ini sebagai orang-orang yang melakukan kegiatan bisnis atau membuka usaha. Dalam berbisnis para pebisnis tentunya tidak pernah memperhatikan latar belakang seseorang, atau melakukan transaksi bisnis dengan pertimbangan suku, agama, dan ras. Hal inilah yang membuat orang Dayak menerima para pendatang dengan tangan terbuka.

Menurut pengakuan Dionus Haryono, ketua dewan adat setempat, masyarakat Dayak tidak pernah mempermasalahkan kehadiran para pendatang di kota Sosok sekalipun para pendatang tersebut berbeda agama selama para pendatang menerima dan menghormati adat, budaya, dan tradisi suku Dayak yang ada di kota Sosok

Dewan Adat Dayak di kota Sosok berusaha untuk selalu mengayomi para pendatang agar dapat hidup rukun dengan sesama warga kota sekalipun berbeda latar belakang agama. Pendekatan yang dilakukan adalah dengan membuka saluran komunikasi diantara lembaga-lembaga atau komunitas-komunitas suku dan agama yang ada di kota Sosok. Tindakan untuk selalu mengayomi para pendatang ditunjukkan dengan cara selalu mengambil inisiatif lebih dahulu dalam berkomunikasi dan berkumpul dengan lembaga atau komunitas suku lain.

Salah satu bukti bagaimana Dewan Adat Dayak di kota Sosok mengayomi dan merangkul pendatang dari suku-suku lain adalah dengan mengumpulkan para ketua-ketua lembaga dan komunitas untuk bersatu menyikapi fenomena Basuki Tjahaja Purnama (Ahok) di Jakarta dalam pemilihan umum kepala daerah DKI Jakarta tahun 2017. Peristiwa politik yang terjadi di Jakarta sekalipun jaraknya jauh berimbas pada kerukunan hidup antarumat bergama di Sosok.

Kasus yang menimpa gubernur Ahok di Jakarta yang sangat terasa imbasnya sampai ke wilayah Sanggau tersebut terlihat dari emosi masyarakat Dayak yang marah atas apa yang menimpa Ahok, namun masyarakat Dayak sadar bahaya perpecahan antar umat beragama di tengah-tengah masyarakat dari kasus Ahok tersebut. Untuk menghindari konflik itulah maka Dewan Adat Dayak di 
kota Sosok mengumpulkan seluruh elemen masyarakat dari tiap-tiap komunitas yang ada untuk membuat pernyataan sikap di atas.

Hasil dari pertemuan yang digagas oleh Dewan Adat Dayak adalah pernyataan sikap bersama dan deklarasi damai yang ditandatangani oleh ketuaketua organisasi kemasyarakatan, paguyuban, tokoh agama, temenggung adat subsuku-subsuku Dayak, tokoh masyarakat dari berbagai suku, dan kepala desa se-kecamatan Tayan Hulu. Jumlah keseluruhan orang yang menandatangani deklarasi bersama tersebut ada 33 orang.

Pernyataan sikap dan deklarasi damai tersebut berisi tentang:

1. Menolak keberadaan ormas yang intoleran yang nyata telah meresahkan dan mengancam keamanan dan ketertiban dalam wadah NKRI, terutama di wilayah hukum Kecamatan Tayan Hulu.

2. Meminta kepada pemerintah untuk segera membubarkan ormas-ormas apapun yang intoleran dan bertentangan dengan UUD 1945, Pancasila, ke-Bhinekaan dan NKRI.

3. Semua pihak masyarakat Adat Kecamatan Tayan Hulu untuk senantiasa menjaga keamanan dan ketertiban dan barangsiapa melakukan tindakan sepihak atas alas hukum suku, agama, dan ras (SARA) di wilayah hukum Kecamatan Tayan Hulu, maka akan disanksi adat 2 (dua) kali lipat dari hukum adat Mandoh Pakat yang didirikan hari ini, dan kasusnya diserahkan kepada pihak yang berwajib untuk diproses secara hukum.

Pernyataan pada butir ketiga di atas memperkuat sikap suku Dayak kepada para pendatang akan pentingnya supremasi hukum adat masyarakat Dayak dalam setiap aktivitas kehidupan sehari-hari. Tradisi dan budaya masyarakat Dayak berada di atas kepentingan atau aturan-aturan dalam berbagai aliran agama. Dengan demikian, masyarakat Dayak menegaskan bahwa agama harus dilihat semata-mata sebagai produk budaya, bukan sebagai produk masyarakat untuk kepentingan politik bagi agama itu sendiri atau para pengikutnya.

Melalui pernyataan sikap tersebut suku Dayak ingin menunjukkan bahwa identitas komunalnya dikenal melalui budaya atau tradisi turun-temurun dari nenek moyang. Masyarakat suku Dayak tidak menonjolkan identitasnya dari sisi agama, melainkan dari sisi budaya. Dan, melalui budaya pula masyarakat Dayak mendasarkan perilaku atau sikap dalam berinteraksi dengan suku-suku pendatang lainnya. Segala masalah yang berhubungan dengan hubungan antar umat beragama harus diselesaikan dengan menggunakan pendekatan budaya, dalam hal ini hukum adat.

Di atas telah disebutkan bagaimana masyarakat Dayak memandang para pendatang sebagai orang-orang yang melakukan aktivitas bisnis. Disini jelas stereotipe yang diberikan kepada para pendatang adalah pedagang atau pelaku bisnis. Masyarakat Dayak melihat bagaimana para pendatang bisa masuk ke semua tingkatan masyarakat tanpa memperhatikan latar belakang orang lain. Sikap baik dari para pedagang atau pelaku bisnis ini diterima dengan baik pula oleh masyarakat Dayak di kota Sosok. Stereotipe pendatang sebagai pelaku bisnis ini menjadi salah satu kunci kerukunan hidup beragama di wilayah Sanggau. 
H.H. Daniel Tambuarian : Komunikasi Lintas Budaya Masyarakat Dayak Dalam Menjaga Kerukunan Hidup Umat Beragama

Selama ini dijaga dengan baik tentunya masyarakat Dayak akan selalu menerima dengan terbuka kehadiran suku-suku pendatang di wilayah mereka.

Namun sebagaimana halnya dengan sifat manusia secara umum yang tidak ingin ditantang, tidak terima bila tidak dihargai, atau marah bila martabatnya terganggu, masyarakat Dayakpun akan marah jika hal-hal tersebut terjadi atas diri mereka. Prinsip yang ada di tengah-tengah masyarakat Dayak di wilayah kota Sosok adalah "kamu jual, kami beli berapapun harganya". Prinsip ini menjadi identitas komunal masyarakat Dayak yang tidak akan pernah memulai sebuah pertentangan, perselisihan, ataupun pertikaian. Sedapat mungkin masyarakat Dayak akan mengalah dan membawanya ke jalur hukum adat. Tapi bila orang lain berani memulai pertikaian, dan tidak mau menghormati hukum adat maka orang Dayak siap membelinya, membayar harganya berapapun yang diminta. Sikap ini bisa kita lihat dari kasus konflik Dayak-Madura di akhir tahun 90an.

Kerukunan hidup antarumat beragama di wilayah kota Sosok Kabupaten Sanggau dilihat dari sudut pandang budaya masyarakat Dayak akan selalu tetap terjaga. Hal ini dimungkinkan karena masyarakat Dayak memandang dan memaknai agama dari sisi budaya. Dalam hal menyelesaikan konflik atau pertentangan pun pendekatan komunikasi budaya lebih diutamakan oleh masyarakat Dayak.

Dialog antar budaya sangat penting bagi masyarakat yang tinggal di wilayah Sosok, karena pada dasarnya dalam menyelesaikan setiap perselisihan atau pertentangan masyarakat Dayak memberikan tempat utama pada pendekatan budaya, sangat menjunjung tinggi budaya dan tradisi yang diturunkan dari generasi ke generasi.

Pada satu sisi, pendekatan dengan cara komunikasi antar budaya akan sangat membantu masyarakat dalam menghadapi perpecahan atau konflik antar umat beragama. Pada sisi yang lain, tidak semua pendatang menerima atau bisa beradaptasi dengan budaya dan tradisi masyarakat Dayak. Selama para pendatang yang berlainan suku bisa menerima, menghargai dan menghormati budaya dan hukum adat, dan menghormati masyarakat Dayak sebagai penduduk asli di tanah tersebut, maka bila dilihat dari sudut pandang orang Dayak konflik antar agama ataupun konflik-konflik sosial lainnya tidak akan pernah terjadi.

\section{Simpulan}

Kerukunan hidup antar masyrakat Dayak dengan pendatang dari suku lain yang berbeda agama dapat tetap terjadi selama para pendatang tersebut menghormati hukum adat yang berlaku di Kota Sosok, Kabupaten Sanggau. Masyarakat Dayak tidak pernah menolak kehadiran para pendatang bila para pendatang tersebut datang dengan niatan damai dan tidak berniat merusak kerukunan yang selama ini telah terjaga.

Penelitian ini memandang kerukunan hidup antar umat beragama di Kota Sosok Kabupaten Sanggau, Kalimantan Barat dari sudut pandang atau kacamata masyarakat Dayak. Hal ini pula yang menjadi kelemahan dari penelitian ini. Penelitian selanjutnya diharapkan mampu menggali informasi dan mengungkap 
pemikiran-pemikiran dari warga pendatang yang berbeda suku dalam memahami kerukunan hidup di kota Sosok, khususnya kerukunan hidup antarumat beragama.

\section{Ucapan Terima Kasih}

Penulis mengucapkan terima kasih kepada narasumber yang telah bersedia menerima menulis dan memberikan kerjasamanya selama proses penelitian ini berlangsung. Ucapan terima kasih juga penulis berikan kepada seluruh masyarakat Dayak di Kota Sosok yang menerima penulis ketika melakukan penelitian. Kemudian ucapan terima kasih juga diberikan kepada Kemenristek Dikti yang telah memberikan dana hibah penelitian dosen pemula sehingga penelitian ini dapat terlaksana.

\section{Daftar Pustaka}

Creswell, J.W. (2003). Research design: Qualitative, quantitative, and mixed methods approaches (2nd ed.). Thousand Oaks, CA: Sage.

Mulyana, Deddy., \& Rakhmat, Jalaludin.(2006). Komunikasi Antarbudaya: Panduan Berkomunikasi dengan Orang-Orang Berbeda Budaya. Bandung: Remaja Rosdakarya.

Samovar, Larry A., Richard E. Porter \& Edwin R. McDaniel.(2010). Komunikasi Lintas Budaya: Communication Between Cultures (Edisi 7). Jakarta: Salemba Humanika.

Sari, Wulan Purnama. (2015). Konflik Budaya Dalam Konstruksi Kecantikan Wanita Indonesia (Analisis Semiotika Dan Marxist Iklan Pond's White Beauty Versi Gita Gutawa). Jurnal Komunikasi, 7,2, 198-206. Terarsip di : https://journal.untar.ac.id/index.php/komunikasi/article/view/18/39

Tubbs, Stewart L, Sylvia Moss.(2005). Human Communication. Singapore: McGraw-Hill. 